\title{
THE HOLOCAUST AND ROMANI ROMANIANS: DEPORTATION AND RESISTANCE
}

\section{SHANNON WOODCOCK ${ }^{1}$}

At the border (of Transnistria) the train stopped. They let us go to the market with the guards. Some Romanians there told us, 'Brothers, you are being sent there for extermination!' - Irimia Gheorghe, Romani survivor

There were two camps. Tigani (Roma) were on one side, and Jews on the other. We watched them dying, they watched us dying. So many were shot. When they saw a Jew-Bang! Shot! When they saw a Tigan-Bang! Shot. -Calin Petre, Romani survivor

In World War II, the Romanian government deported Romanian Jews and Roma to the [artificial] geographical region named Transnistria as racial, political and social threats to the Romanian nation. Bounded by the Dniester and Bug rivers in what is now Ukraine, Transnistria was administered by the Romanian government at Hitler's behest for the period of its existence between summer 1941 and January 1944. This was a territorial incentive for Romania's military role in advancing the Nazi front into Russia in 1941. Under the orders of Ion Antonescu, the antisemitic right-wing prime minister of Romania and ally of the Third Reich, approximately 150,000 Romanian Jews and 26,000 Romanian Roma were deported to Transnistria in 1941 and 1942. ${ }^{2}$ There,

1 This essay is a modified and expanded version of an article that appeared in Interstitio, East European Review of Historical Anthropology, the Free International University, Republic of Moldova, 2009.

2 This is the standard figure agreed upon by the first rudimentary counts of names listed as deported in convoys and on trains in 1942. This number does not take into account the thousands of people recorded as re-deportations and staggered deportations that 
both Jewish and Romani deportees were forced to labour and left to starve and freeze in a haphazard constellation of illadministered ghettos and camps. Approximately 90,000 of the deported Jews and 6,000 Romani Romanians survived to return to Romania in 1944 behind the Russian front. ${ }^{3}$

Just as Jews were deported in groups according to Romanian designations of class and geographical location, Roma were deported in two distinct groups in 1942. The first were Roma identified as 'nomadic Tigani', and the second as 'convicted and dangerous...sedentary nomads'. The first group of 'nomads' were Roma of various ethnic sub-groups (Caldarari, Fierari) who often owned property in villages to which they returned in winter, and who travelled as an agricultural labour force in the summer. The second group comprised individuals with prison records (overwhelmingly for petty crimes, with incarceration periods of less than six months), and included single mothers (as 'morally dangerous'), the families and children of people without an income, and people whom the police deported without noting a justification.

The Romanian deportations of Roma as pejoratively-

continued until late 1944.

3 The survival rate was much lower for Romani deportees, who were also arrested and used as forced labour as they re-entered Romanian territory, according to Ordin Circular no 150.263, 19 April 1944. ANIC Fond Inspector General of the Gendarmeria (Inspectoratul General al Jandarmeriei, henceforth IGJ), dosar 86/1944 f75, f89, f220. It is important to note that Transnistria, including the cities of Odessa and Tiraspol, had a local Jewish population of approximately 300,000 who were massacred by both Romanian and German Einsatzgruppen D soldiers in 1941 and 1942. Total Jewish deaths in Transnistria 1941-1944 are approximated as 260,000. Local Romani communities are not mentioned in surveys of the period outside of the deportations from Romania, though they certainly existed. 
named Tigani is an event in the broader context of anti-Tigan racism as a catalyst for Romanian identity. Understanding the long history of anti-Romani persecution that informed the actions of the Romanian government, police and public in 1942, destabilises continuing assumptions that Roma were rightfully deported as criminals, somehow a social group separate from racialised categories. This blinkered approach to history has thus far ensured that the Romani experience of the Holocaust years is largely unexamined and widely considered 'unknowable'. This essay traces how local police decided who to deport to Transnistria, what happened to deportees in Transnistria, and the ways that Romani Romanians resisted exile and death in the Transnistrian lagar. ${ }^{4}$ The final section documents Romani resistance to the genocide in Transnistria and thus explodes the pervasive assumption of many historians that Roma did not leave a written trace in the archives of the Holocaust. In fact, Romani people who were for the most part unable to read and write, found people to transcribe their letters for them, and they understood the bureaucratic hierarchy and where to direct their petitions. The Romanian archives hold hundreds of letters written by Romani deportees to various Romanian government officials, providing narratives of deportation and the horrific conditions in Transnistria as well as engaging with the racist discursive frameworks of persecution.

\section{A short history of the problem: making Romanians by persecuting Tigani}

The history of anti-Romani persecution in Romanian society must be read in the context of almost 500 years of institutionalised slavery. Between 1385 and 1856, every Romani person who entered the principalities of Wallachia or Moldova was considered a slave of the state. The state could

${ }^{4}$ Note the words lagar and ghetto were used by Romanian police and bureaucrats to describe the Transnistrian prisons. 
retain slaves for their own use, or sell them to boiers (private landowners) or monasteries. Slaves were called sclavi, robi, or Tigani. ${ }^{5}$ Other ethnic groups were also slaves, as with a small percentage of Tartars, but these groups were freed by the end of the 15th century. Only Roma remained slaves. ${ }^{6}$ The term 'Tigan' came to conflate the legal and social position of slaves with ethnic Roma. To be a slave was to be considered ethnically and racially (culturally and biologically) Tigan. There was no such thing as a free Tigan, or a free Rom.

Tigani slaves were vital to the Romanian economy, working the trades of their traditional family groups. The Fierari were metalsmiths, making tools and equipment for farming. Lautari musicians played at village fairs, weddings, and for those who could afford them. The Ursari entertained with their tamed bears, and other Roma worked as horse trainers and traders, gold panners and goldsmiths, traders of small items, as domestic workers and as cleaners. As with slavery elsewhere, Tigani were controlled by a detailed legal and social system; the Tigan as slave was created and scaffolded within an entire system of stereotypes to justify violent enslavement. Elite and subaltern Romanians discursively constructed the Tigan other as lazy and stupid, yet vindictive and cunning; as requiring forced labour and close supervision in all respects. ${ }^{7}$

5 The word 'Tigan' (plural Tigani ) derives from the word 'Tsiganoi' which was widely used in the Byzantine period to name Romani populations that moved west with the Ottoman forces. Roma have consistently identified themselves thus as an ethnic group, and there are a heterogeneous dynamic community of groups within that umbrella term.

${ }^{6}$ Achim, Viorel (1998), Tiganii în istoria României, Bucharest, Editura Enciclopedia, 33.

${ }^{7}$ For a detailed study of the binding stereotypical discourses of 
The pervasive institutional and social stereotyping of the Tigan as the lowest social group and requiring enslavement, especially as they played a vital economic role in society, placated ethnic Romanian peasants. Landowners (when talking to the peasants) and peasants (when talking of themselves) articulated themselves as moral, obedient, and attached to the land -in contrast to the Tigani who would supposedly roam the land and refuse to work at all if they weren't enslaved. In the 1848 Romanian nationalist movement, Mihail Kogalniceanu and other nationalists discursively relied on the manumission (or dezrobirea, literally the 'unslaving') of Tigani as the means to produce a united ethnic Romanian nation, to be civilised and worthy of independence in the eyes of modern Europe. Romanian historian George Potra wrote in 1939 that 'the idea and fact (of dezrobirea) was welcomed by foreigners, from whom we asked for the recognition of certain rights' ${ }^{8}$ The lack of forethought or afterthought regarding what would happen to Romani individuals after slavery is evidence that uncivilised Tigani slaves provided an object upon which the ethnic Romanian nation could cut its humanitarian teeth.

The actual steps taken in the process of dezrobirea were legislative, and these laws dealt with the issue of how much compensation would be paid to owners, including monasteries. There were no government measures, in terms of legislation or social policy, that addressed the supposed change in status of more than 250,000 people. ${ }^{9}$ Tigani

slavery and the interplay of this system with slave resistance, see Hartman, Saidiya V (1997), Scenes of Subjection: Terror, slavery, and self-making in nineteenth century America, New York, Oxford University Press.

8 Potra, George (1939), Contibuțiuni la Istoricul Ţiganilor din România, Bucharest, in the edition republished by Cartea Veche (2001), Bucharest, 111.

${ }^{9}$ The figure of 250,000 is the calculation of Achim, op cit, 98, but 
continued to be called Tigani, but were no longer considered of primary state concern after the final law of dezrobirea in 1856. When a boier's slaves became free men and women, they no longer had the right to live on his property, resulting in large numbers of homeless Roma. Many emigrated and travelled in search of places to stop and work for a living, and these Roma were easily identified by appearance, occupation and landlessness as Tigani. Many made agreements with their former owners to continue living on that land in their employ; these people continued to be called Tigani, despite their legal status as free men. By World War I, the Tigani were no longer considered slaves to be privately owned, but Romani peoples continued to exist socially as Tigani without owners, the internal ethnicised 'others' who required constant policing within the nation.

In 1918, the Treaty of Trianon granted Romania the former Hapsburg territory of Transylvania, more than doubling Romania's area and population. The increase in urban populations of non-Romanians, as well as an overall increase in non-Romanian populations, spurred two decades of Romanian ethno-nationalist policy. ${ }^{10}$ The predominant anxieties of the Romanian state and population in the

Kogalniceanu himself estimated that there were at least 600,000 Țigani slaves in (1837), Esquise sur l'histoire, les moeurs et la langue des cigains, connus en France sous le nom de Bohémiens, Berlin, Librarie de B Behr, Oberwaldstrasse. See also Petcuț, Petre (2008), 'Le lendemain de l'esclavage. Les mesures de l'Etat pour la sédentarisation de Roms' in Anuarul Centrului de Studii Rome 1/2008, Bucharest, Editura Universității din Bucureşti, 23-40. For a fuller discussion on this theme see Woodcock, Shannon 'The Tigani Other as Catalyst for the Creation of Modern Romania' in the same volume, 41-72. 10 See Livezeanu, Irina (1995), Cultural Politics in Greater Romania: Regionalism, nation building and ethnic struggle 1918-1930, London, Cornell University Press. 
interwar period were pinned to the spectres of Jewish urban control, Hungarian irredentism in newly gained Transylvania, and Bolshevism in the East. Romani Romanians were increasingly policed in their socio-economic position as the inferior, marginalised ethnic minority by Romanian state bureaucracy. ${ }^{11}$ From the Romanian perspective, Tigani were considered radically other to, but inextricably of, the Romanian people. ${ }^{12}$

The Romanian fascist movement known as the Legion of the Archangel Michael (later, the Iron Guard), gained strength in the 1930s through physical threats and popular appeal. Racist and antisemitic at heart, the Legionary movement articulated a Romanian nationalism that moved beyond socially pervasive ethno-nationalism to racialise Romanian identity in eugenic discourses on national hygiene resonant with National Socialist ideology. ${ }^{13}$ Newspaper articles and 'scientific' studies conducted by academics at the Central Institute for Statistics described the Romanian nation as a

11 Romanian Romani communities responded to the new ethnonational tensions by forming their own trade unions stressing the modernisation of Romani communities as part of the Romanian nation. They focused on literacy and the unionisation of traditional skills, stressed that they were not a political group, but considered themselves part of Romanian society of ethnicity Rom or Tigan. See Williams, Susan (2007), 'The 'Civilised Trap' of Modernity and Romanian Roma, 1918-1934', in Anthropology of East Europe Review, vol 25 no 2, Fall, 12-27.

12 The 1930 census of Romania concluded that there were 208,700 Tigani in the country (Institutul Central de Statistica (1930), Bucharest), a gross under-representation by comparison with all other estimates.

${ }^{13}$ Romanian fascism, however, is vastly different to National Socialism. See Deletant, Dennis (2006), Hitler's Forgotten Ally: Ion Antonescu and his regime, Romania 1940-1944, New York, Palgrave Macmillan. 
racial body threatened primarily by Jews and Tigani. An article entitled 'Race and National Destiny' in Cuvântul, the Legion's semi-official newspaper, on 16 January 1941 ranted that 'the decline of the Romanian people is due to the infiltration into our ethnic group of elements of inferior races, the crossing of the ancient Getic-Roman blood with Phanariot and gipsy (sic) blood, and, of late, with Jewish blood.' ${ }^{14}$ Sabin Manuilă, director of the Central Institute for Statistics, referred to 'the Tigani problem' as 'the most important and acute racial problem in Romania',15 and suggested in a 1941 memo to Antonescu that 'unilateral transfer' of these populations - to send them outside Romanian borders - was the solution. ${ }^{16}$

Antonescu walked his own line of institutionalised antisemitic and anti-Romani persecution after purging the Legion in January 1941, and in the following years as an ally of Germany with attendant pressure to follow Nazi racial

14 'Race and National Destiny' in Cuvântul XVII (new series) no 91, Thursday 16 January 1941 in Petculescu, Constantin and Florian, Alexandru (eds) The Killing Idea: The dimensions of the Legionary ideology, Bucharest, Noua Alternativa, 359 as cited in Giurescu, Dinu C (2000), Romania in the Second World War 1939-1945, East European Monographs, Boulder Distributed by Columbia University Press, 66. Please note the translator's use of 'gipsy' from Tigani, a common and grammatically incorrect slippage of the Romani subject to the realm of the fantasmatic uncapitalised 'Other' in Western discourse across the centuries.

${ }^{15}$ Cited in Deletant, Dennis, op cit, 189 and referenced to Bucur, Maria (2002), Eugenics and modernization in interwar Romania, Pittsburgh, University of Pittsburgh Press, 147.

16 See Achim, Viorel (2001), 'The Romanian Population Exchange Project Elaborated by Sabin Manuilă in October 1941,' Annali dell'Instituto storico italo-germanico in Trento, 28, 593-617. 
policies. ${ }^{17}$ It is possible to say that Antonescu's racial policies were in line with Nazi genocidal racial policies, although he proved more canny in considering the economic and political effects of deportations of Jews to Transnistria at crucial moments in the war, halting fresh and large-scale deportations of Jews and Roma in 1943 rather than pursuing a 'final solution' as in German-administered territory. Romanian pre-war anti-Romani racism-inherent, reproduced and policed in the naming and marginalisation of Romanian citizens deemed to be 'Tigani' - was thus fully racialised in the fascist decade of Legionary popularity. It was this racially identified group that was targeted for deportation and destruction in the Holocaust alongside Romanian Jews. Antonescu's intent to destroy certain perceived parts of the Romani community (as Tigani) through their deportation, forced labour, and murder in Transnistria, was implemented by members of the Romanian government, military, and the military police, the gendarmerie. ${ }^{18}$

\section{Deportation to Transnistria}

Marshall Ion Antonescu issued two decrees in May 1942; first, for the census of all 'nomadic' and 'sedentary' TTigani, and second, for the deportation of 'all nomadic Tigani'. The specific order to deport 'nomadic Tigani' read:

In line with the general order to remove all parasitical and disorderly elements, Marshall Ion Antonescu orders-

17 See Deletant, Dennis, op cit, for a detailed analysis of Antonescu in relation to Hitler.

18 We can understand the persecution of Roma as Tigani by remembering that Jews (Evreii) were persecuted and identified as the pejorative and stereotype-laden name Jidani (usually translated as 'kike' in English). It is striking to think that while scholars wouldn't dare to refer to Jews by the pejorative names the perpetrators called them, Roma and Sinti are still commonly referred to as Zigeuner, Cigany, Tigani and Gypsies by non-Romani scholars. 
through this act - that all groups of nomadic Tigani from the whole country be sent to Transnistria. These measures are to be executed through local organs of the gendarmerie, so that no group of Tigani and no police can know the final scope of the order. The removal will be implemented by the legions of the gendarmerie. These orders are to be executed immediately. For other categories of Tigani the orders will be given in good time. ${ }^{19}$

The frame for the decree refers to the removal of 'parasitical' elements from Romanian society, in line with racialised discourse of the time. Important is the intentional withholding of information about what awaited deportees in Transnistria, although local police documents continually referred to 'evacuating' deportees to the lagar (prison) in Transnistria. ${ }^{20}$ From the archival evidence, it can be concluded that Romanian gendarmes across the country easily understood who was meant by the category 'nomadic Tigani'. Without confusion, gendarmes identified and deported groups of Caldarari, Fierari and other Romani family units who were beginning their summer work season of travel. These groups often owned property and animals in villages where their families had lived for generations, and travelled on established routes between markets and fairs with their trades in the summer. Their property was nationalised in many cases, and simply taken over or stolen by Romanian inhabitants in other cases. ${ }^{21}$ On 1 June 1942, 11,441 people

${ }_{19}$ ANIC Folder IRJ, dosar 258, f4. 1942, end of May, Order from the President of the Council of Ministers, the Military Cabinet, to the General Inspectorate of the Gendarmerie

20 The verb 'evacuation' and the noun lagar were also used for Jewish deportees.

21 Through Law Nr 315, 30 January 1942. Order to apply this law to the property of deported Tigani sent to all regions on 4 September 1942. ANIC fond IGJ, dosar 126/1942 f10-11. Each case can be 
identified as 'nomadic Tigani' were assembled across Romania and marched on foot under armed guard to Transnistria. ${ }^{22}$ The quotation that opens this essay is from a survivor of this forced march to Transnistria.

The decree for the census of 'non-nomadic Tigani' in May 1942 specified that gendarmes were to deport 'sedentary nomads (especially those who, being non-nomadic, are convicts, recidivists, or have no means of existence or precise occupation from which to live honestly through work, and thus constitute a burden and a danger to public order'). ${ }^{23}$

The lists of non-nomadic Roma sent back to the Council of Ministers were short. Most gendarmerie branches simply wrote 'we don't have any Tigani like this here'. Indeed, while 'nomadic' Tigani were recognisable by their wagons and sometimes their dress, the concept of 'non-nomadic' Tigani did not reference a pre-existing group that could be easily defined and deported. The Council of Ministers ordered the General Inspectorate of Gendarmerie to resolve the lacklustre performances of its regional offices, and on 25 July another telegram was sent to all branches ordering another census of 'all sedentary Tigani who have had prior convictions, are recidivists, or live without a means of existence'. ${ }^{24}$ Gendarmerie who still reported they had no such people in their jurisdiction were ordered by telephone again on 4

verified by checking property registries in regional archives. Many of the soldiers who returned from the front to find their families deported as Tigani also found that local Romanians now owned their property.

22 The figure is from the government count of nomadic Tigani who entered Transnistria as a result of these marches. ANIC fond IGJ, dosar 126/1942, f20-205, 203

2317 May 1942, ANIC, fond Inspectorate Regional de Jandarmi, dosar 258, f-6v,

${ }^{24}$ ANIC, fond DGP, dosar 188/1942, f4-48v. 
August, and finally, on 15 August 1942 the General Inspectorate of the Gendarmerie telephoned every regional branch with the order to return the censuses of 'convicted, dangerous, etc Tigani' on 16 August. ${ }^{25}$ This change of categorical shorthand to qualify 'sedentary nomads' as 'dangerous' indicates a discursive shift in cadence to one of threat rather than 'burden' or 'disorder', in line with the radical racial rhetoric pervasive in policy of 1942.

This series of requests for longer lists of non-nomadic Tigani prompted intense activity and confusion on the ground. It wasn't simply a matter of deporting everyone of Romani ethnicity, or occupation, or colour of skin, though all of these things could signify 'Tigan'. There were clearly darkskinned Romani Romanians who were, by their behaviour, in no way Tigani. Similarly, there were non-Romani Romanians who were disparagingly referred to as 'Tigani' because of their renowned laziness, dirtiness, and generally uncouth, 'un-Romanian' lifestyle-but these Romanians could not be deported as Tigani because they were racially not capable of being Tigani. Individual groups of gendarmes discussed amongst themselves how to identify people to fit the category set for deportation.

In the first place, gendarmes usually trawled prison release lists for anyone they knew as Tigan who had been convicted of a crime. Although the ethnicity of convicts was not usually recorded, gendarmes were working in their own local communities and knew which families were considered Tigan. In the lists they compiled of the sedentary/nonnomadic Tigani, the column beside the names of all the family members to be deported was entitled 'observation' or 'motive for deportation'. The vast majority of those with previous convictions before the law had been in prison for just a few

${ }^{25}$ ANIC, fond Direcția Generală a Poliției, dosar 188/1942, f211. 
months, or had been fined for petty theft. ${ }^{26}$ One deportee in Cernauti was listed for deportation because he had been 'active in a communist organisation' ${ }^{27}$

In the city of Buzau, gendarmes explored the 'Tigani area' around the local market place, and included people who had untidy houses and courtyards for deportation. ${ }^{28}$ In Botosani, the local gendarmes added 155 people to the list of individuals 'to be deported because they don't have certain means of existence...they go from T,igan to Tigan to work, then spend all they earn on food and drink'.29 Similarly, in the city of Roman, the column listing motives for deportation include descriptions like 'he sits in the pub all day'. ${ }^{30}$ In Rimnicu Sarat, the chief of the gendarmes in the village, Ilie Ionescu, had a particular obsession with deporting Tigan women who lived with men without being legally married. In response to the pleas of a father of a deported woman, he wrote that she could not return to Romania because 'she had lived as a concubine with different men, floating between the most dubious of them'. ${ }^{31}$ In Timişoara, the Commander of Timiş-Torontal gendarmerie, Major I Peschir, argued for 'cleansing the Romanian race of Tigani', which mirrors the discourses of racial hygiene prevalent in Hungarian, Romanian and German literature available in Timişoara of the

26 There are clear patterns in the police files I have seen of overrepresentation of Romani Romanians in sentences for theft in the 1930s.

27 USHMM (United States Holocaust Memorial Museum) IGJ dosar/Reel 23, 408.

28 Prefectura Judetul Buzau, dosar Nr 26/1942 ‘Privitor pe Tigani nomazi' file 39, 6 May 1942.

${ }^{29}$ USHMM, IGJ dosar/Reel 23, 353 Legiunea Botoşani, Inspectoratul Jandarmerie Iaşi.

30 USHMM, IGJ dosar/Reel 23, 389.

31 USHMM, IGJ dosar 86/1942, 1148/9. 
time. ${ }^{32}$

The titles gendarmes gave to the lists of non-nomadic Tigani also indicate the different ways that local gendarmes articulated who they were to deport. In Storojinet, gendarmes made a list of 'dubious sedentary Tigani' ${ }^{33}$ In Lapuşna, 690 people were listed in the category 'Tigani to be evacuated from the categories of the dubious, convicted, thieves, pickpockets and those who occupy themselves with stealing from which they win their existence' ${ }^{34}$ On this list of people to be deported are women who read palms, beggars, and the families of people with prior convictions for anything at all.

In one of the Bucharest gendarmerie, the census of nonnomadic Tigani was entitled 'stable Tigani who have been convicted of crimes, are recidivist, etc' but the list was primarily constituted by 'war invalids, children, concubines, workers, lautari, flower sellers, vagabonds, and even a small shop owner'. ${ }^{35}$ The list of another Bucharest gendarmerie used 'dubious occupation' as a category in the column for motive of deportation. ${ }^{36}$ Many Bucharest gendarmes simply left the 'observation/motive for deportation' column blank, or wrote 'no occupation'. Yet in these very documents from Bucharest, the column listing property is often filled with at least a cow or sheep, and regularly with houses. Considering that these individuals had not been convicted of any crimes - on the contrary, they lived a sedentary lifestyle in houses with a few

32 Inspectorate Jandarm Timis-Torontal, dosar 27, 1942, 1.

33 USHMM IGJ Reel 23, dosar 290/1942, 417.

34 USHMM IGJ Reel 23, dosar 290/1942,447.

35 USHMM IGJ Reel 23, dosar 290/1942, ‘Prefectura Poliției Capitalei', 471-74.

36 USHMM IGJ Reel 23, dosar 290/1942, 490. Legiune Jandarmerie Vlasca, Inspectoratul Jand. Bucuresti. 
animals in the suburbs of Bucharest-they could not fit technically in the category of 'dubious occupation'. This is until we consider, of course, that simply being interpellated as Tigan made the semblance of a respectable Romanian lifestyle an unacceptable parody of racial and social organisation, powered by the anxiety of Romanian ethno-national identity that the Tigani 'other' be recognisable as such.

When the regional gendarmerie branches returned their revised and lengthened lists to the General Inspectorate of Gendarmerie, they included letters explaining the revised numbers. The gendarmes of Dolj added 1,227 people to the list, and explained that the first list had been 'superficial' and limited by time. ${ }^{37}$ Commander Gh Tofan of the Vaslui gendarmerie wrote that they 'weren't conscientious enough on the first census' ${ }^{38}$ Others presented their orders to increase the lists as their own acknowledgement of how this is useful for Romanian society - for example, Commander Cristescu in Valcea wrote that he had 'put (on the list) people who are predisposed to commit all kinds of infractions, having decided that this is the moment to rid ourselves of these insubordinates of public order and security'. ${ }^{39}$ Needless to say, only ethnic Roma thus suspected were listed and deported; no other ethnic groups of 'insubordinates' were targeted, thus proving again that deportees were targeted as an ethnic-not a 'social'-group. In Ialomita, an extra 308 people were added to the original 159, all in the category of 'people who own no property, have no occupation and are living off dishonest work' ${ }^{40}$

The ad hoc development of the very concept of non-

37 USHMM IGJ Reel 23, 98 and IGJ Reel 23, 240, amongst many others.

387 August 1942 USHMM IGJ Reel 23, 392.

395 August 1942 USHMM IGJ Reel 23, 207.

40 USHMM IGJ Reel 23, 240. 
nomadic Tigani to be deported shows that the category did not simply refer to a recognisable and pre-identified group. The terms on which such a category were to be applied, on the contrary, were developed in regional variations when local gendarmes responded to simple pressure; they invoked and applied historically developed and contextualised stereotypes of what it meant to be Tigan.

Between 12 and 20 September 1942, 13,176 Romani Romanians were deported to Transnistria on overcrowded trains as sedentary Tigani. ${ }^{41}$ Reports written by the gendarmes in charge of taking Romani from their homes and putting them on trains to Transnistria, recorded the deportees physically resisting deportation. Like Jews, Romani deportees were not only heavily guarded, but lied to and told they would be given property in Transnistria in order to gain a degree of compliance of the victims in their deportation. In multiple cases this led to mass panic and officials in Bucharest sent orders that police were to stop spreading such false rumours.

\section{Resistance to genocide in Transnistria}

Roma, as with Jews, crossed the Dniester river under armed guard with constant beatings and searches. In Transnistria, Roma were settled in a variety of camps - some entirely in the open surrounded by armed guard, some on the collective farms of the Ukrainian state, and others in the houses of evacuated local peasants. Romani camps were primarily in the regions of Oceakov (Alexandru camp), Berezovka and Balta. As Ioanid has pointed out, 'the Gypsies (sic) suffered the same fate as the Jews; they died either by execution or

${ }^{41}$ The numbers are certainly more than this in total, considering continuing arrivals and those who were not on the deportation lists or counted (later acknowledged in police and government correspondence). ANIC fond IGJ, dosar 126/1942, f204-05, 203. 
because of the cold or hunger'. ${ }^{42}$ Having had their wealth, wagons and means of making a living confiscated, Roma were then at the mercy of the horrific winter of 1942, the resulting starvation and typhus epidemics, a total lack of Romanian administrative provision for Roma, and the cruelty of Romanian and German armed forces. ${ }^{43}$ While the Romanian government maintained dialogue with the various international Jewish associations, which in turn secured the delivery of some financial and aid assistance for Jewish deportees, Romani Romanians had no such international assistance. Roma were not considered a factor in international relations during the war. ${ }^{44}$

42 Ioanid, Radu (2008) in the chapter 'The Deportation, Persecution, and Extermination of the Gypsies' in his book The Holocaust in Romania, United States Holocaust Memorial Museum, Washington DC. While this sentence appears in the online edition of the text available at http:/ / www.romanianjewish.org (last accessed 12 September 2008), it does not appear in the print edition.

${ }^{43}$ For more details of the conditions in Transnistria for Romani deportees, see Ioanid, ibid, Achim, Viorel (2004), The Roma in Romanian History, Budapest, New York, Central European University Press, and Michelle Kelso's groundbreaking documentary film Hidden Sorrows: The Persecution of Romanian Gypsies in WWII (available from the author, contact michellekelso@yahoo.com). ${ }^{44}$ For more on Jewish experiences of Transnistria see Carp, Matatias (1994), Holocaust in Romania 1940-1944, Budapest, Primor Publishing; Braham, Randolph L (ed) (1997), The Destruction of Romanian and Ukrainian Jews During the Antonescu Era, Boston, East European Monographs no CDLCXXXIII; Ancel, Jean (ed) (1986), Documents Concerning the Fate of Romanian Jewry During the Holocaust Jerusalem, the Beate Klarsfeld Foundation; Iancu, Carol (2001), Shoah in România: Evreii în timpul regimului Antonescu 1940-1944, Editura Polirom, Iaşi; Butnaru, I C (1992), The Silent Holocaust: Romania and its Jews, New York, Greenwood Press; Institutul Român de Istorie Recentă (2004), Holocaustul evreilor români: Din mârturiile supraviețitorilor, Iaşi, Editura Polirom. 
The following extract from an anonymously authored 'State of Affairs' report dated 5 December 1942 provides one example of the recorded situation of one part of the Romani deportees:

During the time that they have spent in the barracks in Aleksandrodar, the Tigani have lived in indescribable misery. They weren't sufficiently fed. They were given 400 grams of bread for the ones that were capable of working and 200 grams each for the elderly and the children. They were also given few potatoes and, very rarely, salty fish, and all these in very small quantities. Due to the malnutrition, some of the Tigani-and these make up the majority - have lost so much weight that they have turned into living skeletons. On a daily basis-especially in the last period-ten to 15 Tigani died. They were full of parasites. They were not paid any medical visits and they did not have any medicine. They were naked...and they didn't have any underwear or clothing. There are women whose bodies...were [completely] naked in the true sense of the word. They had not been given any soap since arriving; this is why they haven't washed themselves or the single shirt that they own.

In general, the situation of the Tigani is terrible and almost inconceivable. Due to the misery, they have turned into shadows and are almost savage. This condition is due to the bad accommodations and nutrition as well as the cold. Because of hunger...they have scared the Ukrainians with their thefts. If there had been some Tigani in the country who were stealing...out of mere habit, here even a Tigan who used to be honest would begin stealing, because the hunger led him to commit this shameful act.

Due to maltreatment, by 25 November, 309 T,igani had died. Roma bodies were found on the Otchakov Aleksandrodar road. They died of famine and cold. 45

45 State of Affairs report from Oceacov region 5 December 1942, ANIC fond IGJ, dosar 130.1942, vol 1, f128-31. This English 
In this situation of chaos, lack of provisions, and widespread death in the community, many Romani developed complicated strategies for escape. Deportees such as Ion Stancu wrote long complaints detailing the misery and injustice to Bucharest and many built networks with Romanian soldiers to create an underground trade in counterfeit travel permits. Like some Jewish deportees, Roma found ways of making business, trading, and stealing to procure food for their starving and sick families. Evidence of this resistance, on individual and group scale, can be found throughout the Romanian archives. Deported and persecuted Tigani also engaged bureaucratically with the Romanian government to contest and refute the 'status' by which they had been deported. Romani petitions for repatriation submitted to the Ministry of Internal Affairs were forwarded with clarification requests to the regional police in the complainant's village, who conducted their own investigation and replied to the Ministry. Only the miniscule number of individuals who had requests for repatriation approved and had left before January 1943 made it home before the borders were closed to all Tigani seeking return to Romania for fear of typhus epidemics. Roma imprisoned in Transnistria, however, continued petitioning the authorities throughout the war. This paper trail thus documents the active resistance of deportees and the gamut of localised Romanian reactions to and interpellations of Romani ethnicity in wartime Romania.

I focus on 'bureaucratic' resistance here to highlight the wealth of written sources concerning Romani Romanians and the Holocaust. Roma accessed scribes to write their petitions and submitted them to local gendarmerie offices, regional

translation is taken from the chapter 'The Deportation of the Roma and their Treatment in Transnistria' in (2004) The report of the International Commission on the Holocaust in Romania. This report was compiled by a board of historians at the request of Ion Iliescu then President of Romania, overseen by Elie Wiesel. 
town halls, and directly to the Ministry of Internal Affairs and the General Inspectorate of the Gendarmerie in Bucharest. Requests were made by the heads of deported families (especially of nomadic Roma, in December 1942), by soldiers who returned on leave from the front to discover their families had been deported, and by extended family members who endeavoured to bring back their deported family members. Deportees and their family members dictated petitions to scribes, and thus provide narrative constructions of the deportations and interrogations of discursive interpellations of the victims as Tigani rather than Romanian citizens of Romani ethnicity. Many petitioners travelled without or with falsified permits between Bucharest (Ministry of Internal Affairs, General Inspectorate of Gendarmerie) and their home village, and some even travelled clandestinely to Transnistria on multiple occasions to check on their family, then returned to continue petitioning for their return. For escaped deportees, the extra element in the fight was to avoid arrest while 'lingering' outside official buildings trying to speak to clerks about the case. Briefly, avoiding arrest for travelling and simply being in Romania without permission required in itself a high level of discursive agility and physical mobility. Many of these escapee petitioners were arrested and re-deported to Transnistria at least once, and most often with a group of other Roma rounded up by local authorities.

Let us examine a few examples of how these requests for repatriation can be read in order to raise new questions and provide new voices in what I term the bureaucratic resistance of Romani Romanians imprisoned in Transnistria. First, look at the following returned soldier's narrative of realising his family were deported to Transnistria.

9 January 1943

Domnul Prefect,

The undersigned soldier Tudor Mamai, Reg. 21, Infantry, Bucharest, 
respectfully brings the following to your attention:

I fought at the front for 18 months, and in Stalingrad, in which time I had no kind of vacation. This month I was granted leave for 25 days and I returned home to my family in Comuna Balateşti, Jud. Ilfov. When I got home I entered the courtyard and met a stranger who asked me what I was looking for in his house at this late hour. On my own property I asked him what he was looking for in my house. Later I found that my family had been sent to Transnistria, Comuna Bogdanovca, because we are Tigani.

At present I am serving with Reg. 21 Infantry which is at the front in Stalingrad, but I have a permission of leave for 25 days, please give a permission to return for my family, composed of my wife, Anica Mamai, and the child Ion Mamai. My true father Constantin Mamai, my mother Florea Mamai, my uncle Nicolae Raducanu, my brother in law Gheorghe Steian, my brother Dinu Ion Mamai, and my uncle Tanase Costea, and Steian Nicolae, the brother of my wife, Petre Medin my brother in law, and my uncle Dinu Lean. I am decorated with the Military Virtue (medal).

With profound respect, Tudor Marin. ${ }^{46}$

This narrative of a soldier coming home to find his family deported was common. The use of the term Tigan as a simple unproblematised identity term, as we see in this letter, is actually quite rare, reflecting the fact that it was written before the news that Romani Romanians were being deported as Tigani reached even the front lines of Romanian regiments. In Tudor Marin's narrative, being a Romanian T,igan in no way excluded the right to own property, and the letter reminds us that Romani Romanians identified as Tigani were not excused or prevented from fighting in the Romanian army.

The variety of discourses that petitioners use to refute and nuance the interpellation of their families as Tigani are also indisputable evidence that Romani individuals and communities did engage with the power structures in which

46 USHMM IGJ dosar 59, 1942, 1056. 
they were named and persecuted. ${ }^{47}$ Many argued for repatriation by invoking multiple discourses of national identity, familial love, and legal concepts of justice as tied to nation and state. Many petitioners also tried to work within the definition of Tigan which they perceived to have been given by the government to claim their family were mistaken for nomadic or non-nomadic Tigani, in various ways.

In one letter, Vasile and Teca Covaci from Comuna Acmariu in Judet Alba, requested the return of their four children. ${ }^{48}$ They stated:

We are Roma, and thus legally married and these are all our legitimate children. We are not nomadic Roma, we are Fierari, with property and a household and we move for work, to earn a living. At the time they were taken we were at work and the children were mistakenly taken with the other Roma. We hope that you understand our pain as parents remaining without our children, and give permission for them to return.

47 This seems obvious, but in the fields of both Holocaust studies and Romani studies in general, inaccurate stereotypes of Romani relationships to events of politics and history are often used to excuse poor research by non-Romani scholars. For example, the fact that illiteracy was higher amongst Romani interwar communities than non-Romani, and also the fact that due to various factors Romani culture is more an oral tradition than written, does not mean that Romani voices in and about history cannot be read in archival sources. Subaltern and post-colonial studies have demonstrated this. Oral histories also need to be recognised in more formats than the singular controlled interview standard of most Holocaust survivor testimonies being recorded by the United States Holocaust Memorial Museum, Yad Vashem and the Shoah Foundation. An example of more fitting oral history methods might be allowing survivors and their families to talk in groups in order for familiar discursive patterns of shared narration to be documented.

4827 January 1943 USHMM IGJ dosar 59, 1942, 1096 
The petitioners here refer to themselves as Roma, and stress that their familial structure is the same as Romanians (marriage, legitimacy). They also stake a claim for the validity of their lifestyle as property owners who travel for work, yet it is their replacement of the term 'nomadic Tigani' with 'nomadic Roma' that tethers their self-identified ethnic identity to that of the pejorative Tigani 'Other' to be deported. This discursive attempt to replace the government's category with the Romani category of Fierari, a respectable traditional trade-based identity, serves to incorporate the group of selfidentifying Fierari into the gendarmerie's definition of nomadic Tigani. In fact, after much paperwork and investigation between various regions, the gendarmerie found that this entire family had been deported to Transnistria, and the father (Vasile Covaci) had escaped, returned to his home town to make the petition, and continued to live on the run. A search warrant was released for his arrest and he was redeported to Transnistria in April 1943.

This is a petition from a sedentary war veteran:

Ion D Paun 13 February, 1943.

Dear Minister,

The undersigned Ion D Paun, invalid of the war, resident in Com.

Miloseşti Jud. Ialomita, respectfully brings the following:

On the 15th of September 1942, my family were coming home from agricultural work in Comuna Tandarei, and were stopped on the road by gendarmes and included in the convoy of nomadic Tigani, and deported to Com. Cavaliopca, Jud. Oceacov, Transnistria.

This was a mistake, because my family are not nomads, but have lived in Jud. Ialomita for generations, working as useful and established tradesmen. On the other hand, I cannot work anymore due to injuries from the war, thus please repatriate them, as a passionate people caught up in a momentary mistake, without any cases against them, and known as having only acted for good in society.

Thanking you, and receive please my respect and trust for this 
consideration.

Ion D Paun ${ }^{49}$

Ion D Paun doesn't refute the categorisation of his relatives as Tigani, but as nomadic Tigani, and by claiming that they were returning from agricultural work he refutes the stereotype that Tigani don't work the land as do ideal Romanian peasants. The location of his family on land and property over generations is supplemented by his selfpresentation as a good Romanian veteran of World War I. The intent to destroy all Tigani of particular groups is made clear in the subsequent decision of the General Inspectorate of Gendarmerie, that because this family did travel in the summer for agricultural work they were correctly deported as nomads, and because this man is unable to work and thus guilty of avoiding deportation, he was also to be deported to Transnistria. ${ }^{50}$

Cases written by sedentary small business-owning Romani Romanians in large cities often mobilised more strident nationalist discourses to request repatriation. Dumitru Marin typed his own request letters and petitioned multiple times over the period of the war. The following excerpt from the much longer letters he sent to the Minister of Internal Affairs highlights the stereotypical symptoms of 'Tigani' that he refuted in those deported, such as criminality, lack of loyalty to the Romanian nation, and nomadism. In addition, he reminds the government that Tigan Romanians (sic) fought for Romania in the Great War, thus claiming an ethnicity within the Romanian national community called Tigan.

Dear Minister,

My relatives are serious people, honest, workers and home owners,

49 USHMM IGJ dosar 59, 1942, 905.

50 USHMM IGJ dosar 59, 1942, 903 
not one has any criminal records against them...In this family there were people in whose veins flowed the coagulated blood of the holy greater Romania.

Even though I am of Tigan origin, I have lived my whole life a Romanian life, and we identified with the obligations and aspirations of the Romanian people (neam). No blame, no reproach, against any one of these banished from their property and their beloved country can justify their deportation to a foreign land. I ask you respectfully with all my soul to remember that in the Great War there were Tigan soldiers of Tigan origin and you have seen with how much generosity they gave their blood for our country - because they do not have any other. ${ }^{51}$

The Romanian government had decreed on paper that all veterans of World War I, and soldiers and families of active soldiers or potential conscripts for World War II, were to be exempt from deportation. In practice, this decree was never seriously considered. The government investigation found that half of Dumitru Marin's family had not even been included on any census or deportation list-another of the uncountable number of Romani Romanian families deported to their deaths in Transnistrian ghettos without evidence other than these petitions. They were not given permission to return to Romania.

Rafaila Raveca wrote her petition in February 1943 and was clearly aware of the government decree to not deport the families of soldiers currently serving:

The undersigned Rafaila Raveca, living in Posaga de Jos in Jud. Cluj Turda, unmarried with 3 children, brings it to your attention with honour that my daughter Maria, married to Nuț Emil, all living in this commune, was taken away together with the 4 year old child and deported to Transnistria because we are of ethnic origin Tigani. In this case, the fact her husband, Nut Emil, is a mobilized soldier currently fighting at the front in Reg. 85 Infantry, Comp. 3A wasn't

51 Dumitru Marin, 29 December 1942, USHMM IGJ dosar 59, 1942, 899. 
considered. They were illegally deported...without any consideration of the injustice this is for those fighting for the rights of the People, and of the country. ${ }^{52}$

The following petition by a soldier home on leave from active service doesn't mention ethnicity in terms of Romani or Tigan identity, but petitions from the premise that the local police chief abused his personal authority in order to deport his family:

February 6, 1943

Dear Minister of the Interior

The undersigned Munteanu Petre, commercial trader from Comuna Caushani Jud. Tighina, currently a soldier in Regiment 3 Border patrol Cernauti, Comp. V-a Cauşani, respectfully puts the following complaint:

Due to the work of enemies, my parents Simion Munteanu and Sofiea Munteanu, my brothers Ilie and Gavril Munteannu, and also my sister Olga, married to Berdaga Haralambie, all stable residents owning land and property and living for decades in Comuna Cauşani, Jud. Tighina, were rounded up by the Chief of Post in this comuna and taken to Comuna Sustacova, Jud. Oceacov to the state company there.

Soon the fatherland will send me to fight for the integrity of its borders. It causes me pain to do this thankfully when I know my parents, without any guilt and under the holy cross of justice, were sent to suffer there with foreigners.

I ask you, Minister, to conduct an investigation to ascertain that my parents were sedentary people and good citizens and that the Chief of Police in our comuna expelled my relatives to this far away part of

52 Rafaila Raveca Jud. Cluj Turda, February 1943. USHMM IGJ dosar 59, 1942 Doc 1030. The local gendarmerie replied that the daughter of the complainant was deported because she 'refused any work she was offered by the locals and was only interested in living by begging and stealing from their gardens'. USHMM IGJ dosar 59, 1942, Doc 1028. 
Transnistria as an abuse of his power. After this research please give permission for my parents and brothers to be free to return to the comuna where they have lived for decades and where they were born. Please find the certificates from the Mayor's office attached, I send my respect,

Petre Munteanu. 53

The Chief of the Section of the Cauşani gendarmerie replied on a small piece of paper with two sentences stating that this family no longer owned property in the village, and that they were musicians who worked by going from place to place, and thus were nomadic Tigani. This reply, as with the others, provides the historian with insight into how the factors of local property development and fluid government categories for 'Tigani' intertwined. The reply of the Chief does not specify what property the family had owned before they were deported, and all deported persons' properties were nationalised or bought by bystander Romanians. The paperwork remains today in regional archives of the municipal administration. The Chief's designation of the Munteanu family as musicians - who obviously need to work by travelling to functions, including public fairs - as nomadic Tigani, illustrates that even socially integrated and vital community service providers were deported in many cases as nomadic Tigani, primarily because they were perceived as ethnic 'Others' to the Romanian decision-makers.

\section{Conclusion}

The repatriation requests of Romanian Romani deportees to Transnistria as Tigani highlight the need for critical attention to how categories describing potential victims of genocide are formed, disseminated, rearticulated, and enacted. The ways that Romanian officials named and deported 'Tigani' between 1942 and 1945 need to be approached in their historical context of more than 500 years of intense discursive 
construction of the Tigan as enslaved and inferior other against which an ideal ethno-national Romanian identity was articulated. Antonescu's order to deport the non-nomadic Tigani is a way for us to look at how individuals and authorities in different regions decided how to identify nonnomadic T,igani from amongst Romanian Romani communities. Categorisations using words like 'dubious', 'dangerous', and 'immoral' tell us a lot about the stereotypical construction of these others which, in times of non extreme stress, were implicit and articulated in much more subtle ways. The requests for repatriation are valuable evidence of how some Romani Romanians engaged with and refuted these discursive constructions in a myriad of dynamic ways in order to survive. While the majority of those deported to Transnistria died of starvation and disease in barren ghettoes, those who did survive not only continue to tell their stories of endured atrocity, but are supported by a wealth of traditional historical sources that evidence their contemporaneous struggles for recognition and survival. 